\title{
Determine the distribution of a normal range of hematological factors in a sample of the adult population resident in Birjand- South Khorasan, 2015
}

\author{
Khadijeh Gholami $^{1}$ (i), Masood Ziaei ${ }^{2}$ (D), Gholamreza Sharifzadeh ${ }^{3}$ (D), \\ Gholamreza Anani Sarab 4 \\ ${ }^{3}$ Social Determinants of Health Research Center, Birjand University of Medical Sciences, Birjand, Iran \\ ${ }^{4}$ Corresponding author; Infectious Diseases Research Center, Birjand University of Medical Sciences, Birjand, Iran.
}

${ }^{1}$ Student Research Committee, Birjand University of Medical Sciences, Birjand, Iran

${ }^{2}$ Infectious Diseases Research Center, Birjand University of Medical Sciences, Birjand, Iran Email:ghansa@yahoo.com_Tel:+9856323816189_Fax:+985132631600

\begin{abstract}
Background and Aim: Hematological values in people are affected by various factors such as race, environment, time, test method, sample collection site, and age. Given the fact that these factors can differ with each other in different populations, these differences can lead to differences in the results of hematological reference rates.

Materials and Methods: In this cross-sectional study in 2015, a crowd of 5,000 selected from cluster-based adults in Birjand in 2015 and hematological parameters were determined in 4360 healthy subjects. Finally, the data were described using descriptive statistics.

Results: The counts for the total white blood cells, red blood cells, Hemoglobin, Hematocrit, and Mean cell volume values for males and females were determined. The mean Hemoglobin values were $15.01 \pm 3.13$ and $14.01 \pm 1.8$ in male and female respectively and the mean Hematocrit was $45.81 \pm 7.52$ and $42.59 \pm 5.99$ in males and females, respectively. The minimum leukocyte counts were lower than those reported in existing references. However, a higher rate of Eosinophil and Monocyte was obtained among the subjects.

Conclusion: Although in general, hematological factors in Southern Khorasan are similar to the values mentioned in other references, but in some cases, there are also differences that can be useful in evaluating them.
\end{abstract}

Key Words: Normal range; Reference rates; Hematological parameters 


\title{
تعيين توزيع محلدوده ذرمال فاكتور هاى خونشناسى \\ در يك نمونه از جمعيت بالذغ ساكن بير جنل- \\ خراسان جنوبى، سال
}

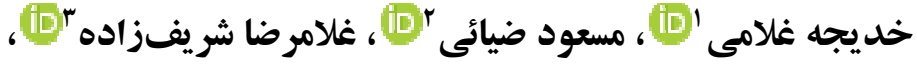

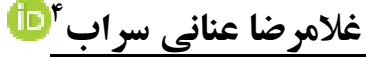

\section{جكيده}

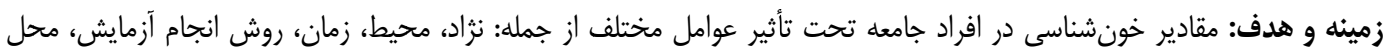

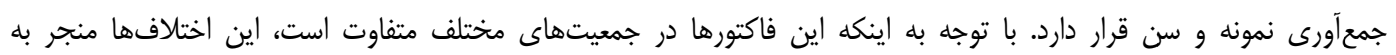

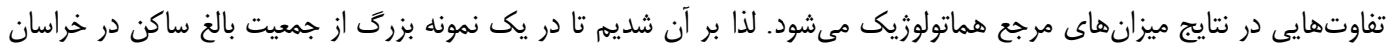

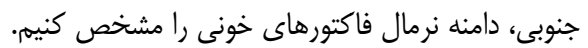

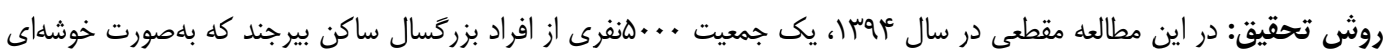

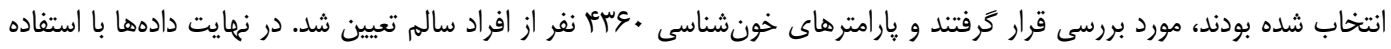
از آمار توصيفى شرح و توصيف كَرديد.

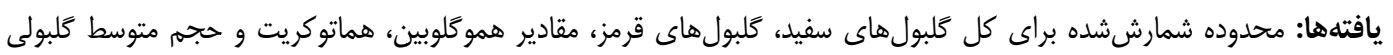

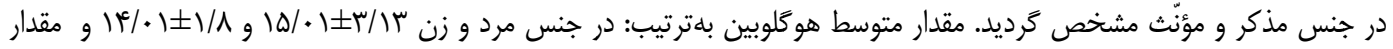

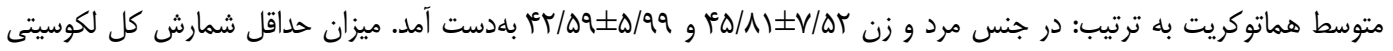

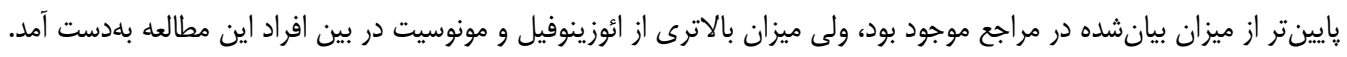

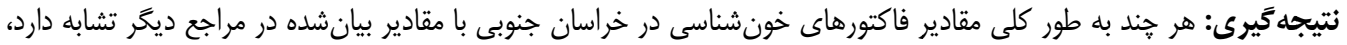

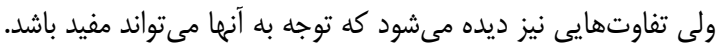
وازههاى كليدى: محدوده نرمال؛ مقادير مرجع؛ فاكتورهاى خونشناسى

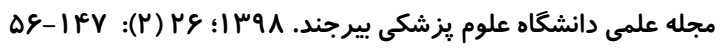
دريافت: •

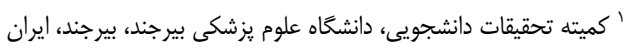

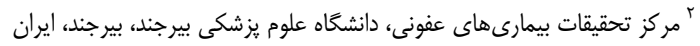

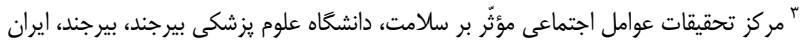

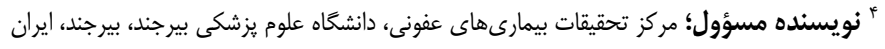


بلهور طبيعى در زنان كمتر از مردان است (V، ج). توصيه

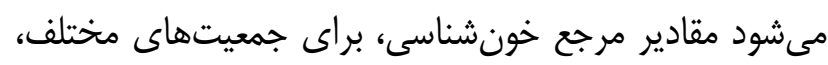

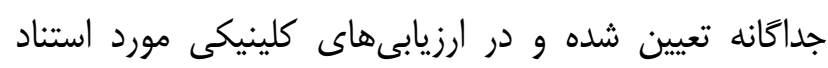

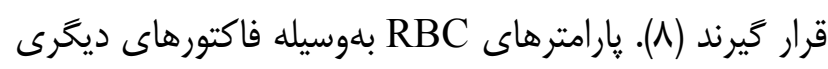

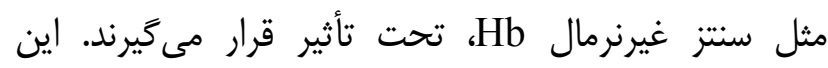
حالتهاى غيرنرمال مىتواند بر اساس بيمارىهاى كاى خلبول

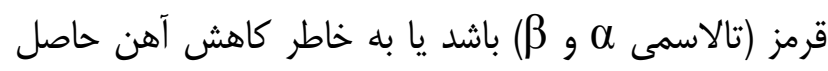
شود (تالاسمى و كمبود آهن، هاييوكروميا را توصيف مي كى كند).

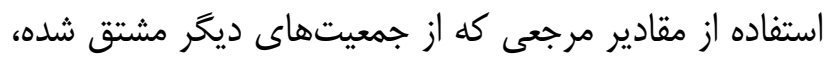

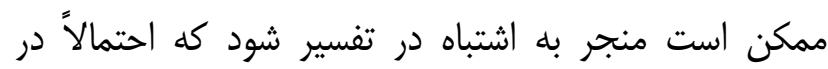

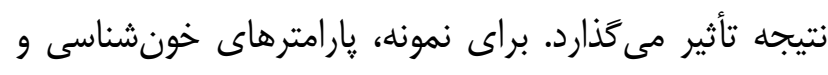

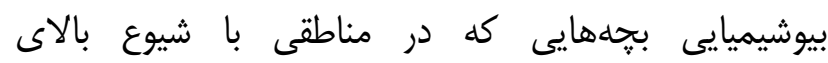

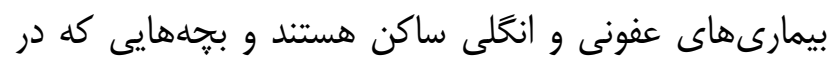

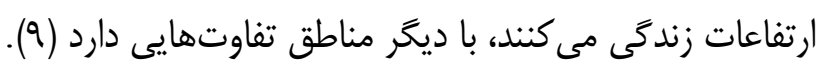

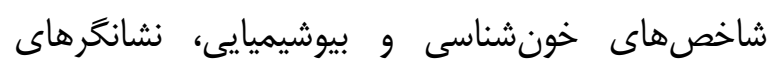
مهرى هستند كه در كارهاى تشخيصى بلهطور گستردي استفاده مىشوند. تعيين مقادير مرجع دقيق و مناسب براى داري

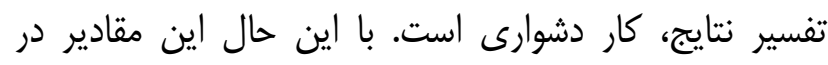

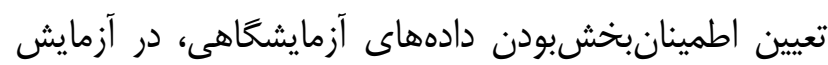

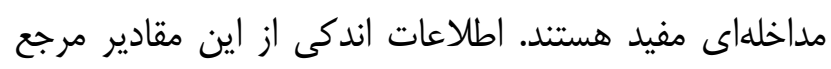

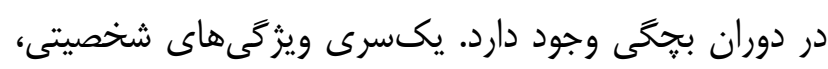

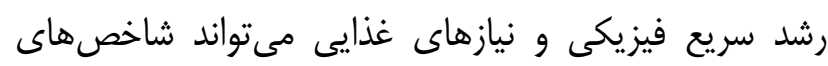

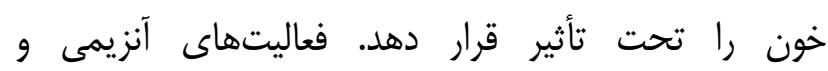

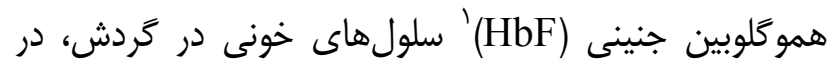

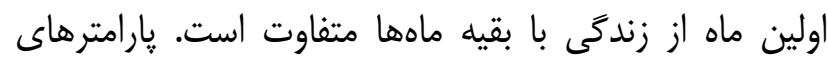
خونشناسى ممكن است كه در مقادير مرجع براى زروههاى

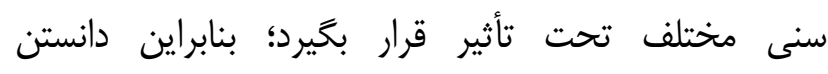
تفاوتهاى مراجع نرمال براى تستهاى آزمايشگاهى روتين تئن

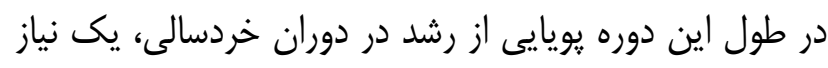

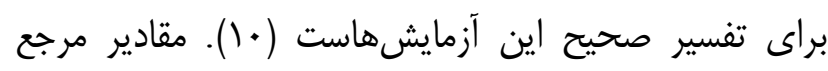

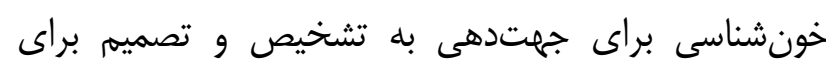

\footnotetext{
${ }^{1}$ Foetal hemoglobin
}

مقلdمه

مقادير خونشناسى بلهور گستردهاى در بررسى وضعيت

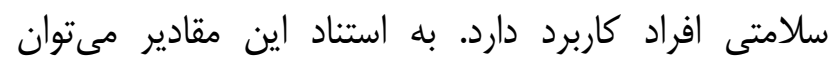

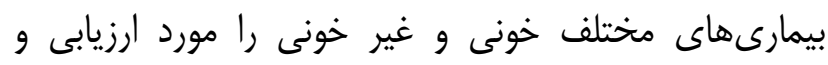

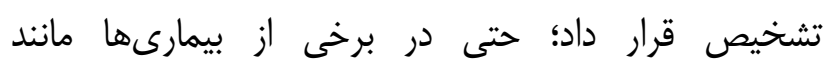

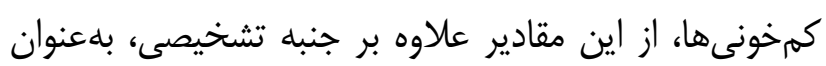

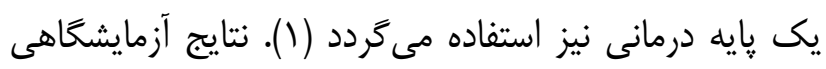

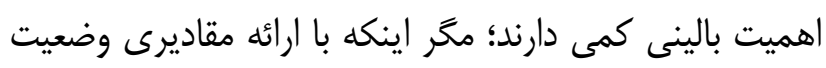

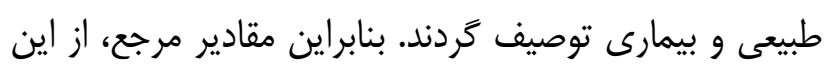
نظر مهم بوده كه ارائهدهنده نتايج يك جمعيت به به ظاهر سئن سالم

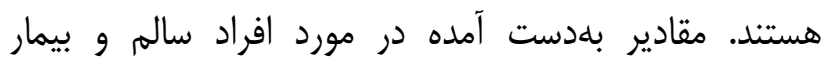
مىتواند هميوشانى قابل توجه با يكديخر داشته باشد. بنابراين

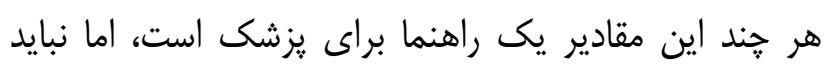

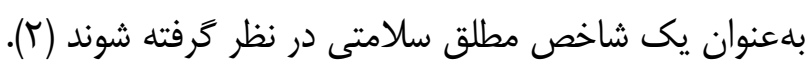

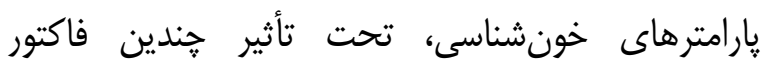
هستند؛ حتى در جمعيتى كه به ظاهر سالم هستند. اين

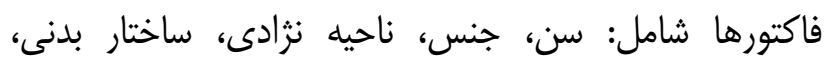

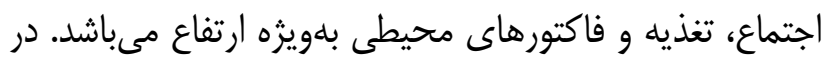
تمام مطالعات، تفاوت قوميت و جنس مشاهده شده است. اين

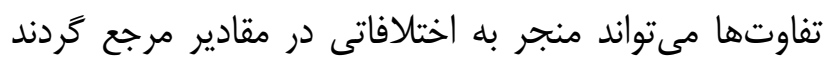

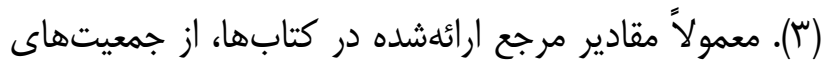

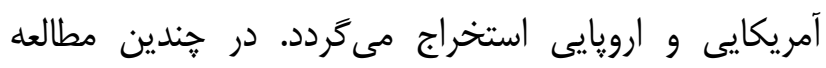

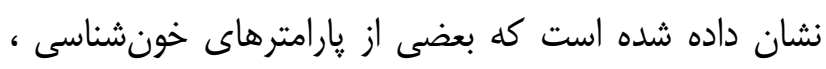

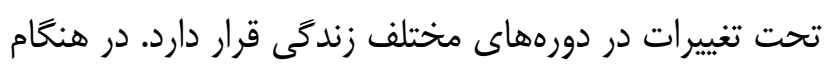

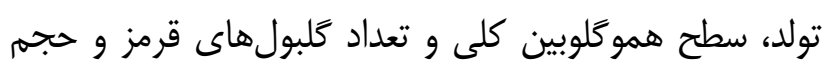
متوسط يلاكتى بالاتر از هر دوره ديخرى نشان داده شده است فئ

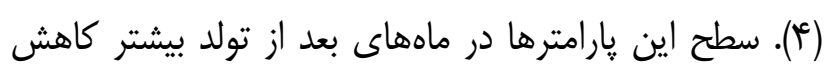

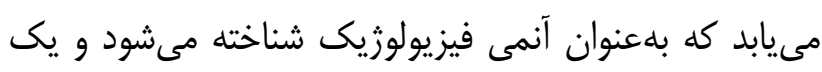

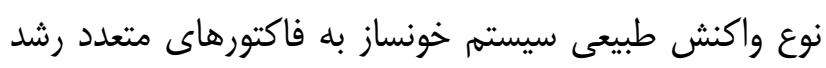

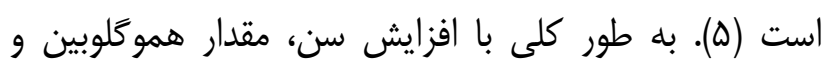

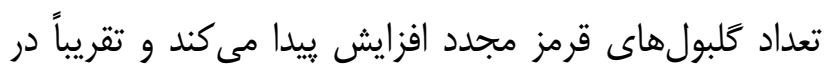

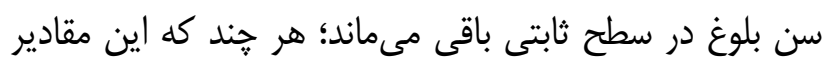


درمان مهم هستند؛ همجنين اين مقادير براى تعيين ايمنى نيز طبرستانى باعنوان دامنه نرمال يارامترهاى خونش شناسى آورده

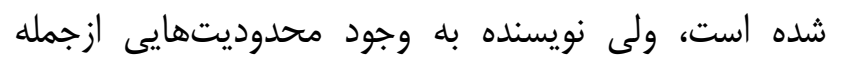
محدوديت در امر جمعآورى نمونه از جنس مؤنّث نيز اشاره

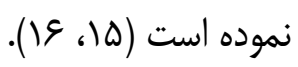

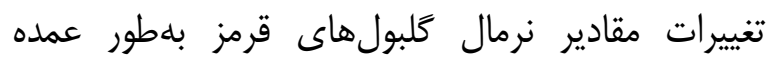

مبتنى بر سن، جنس و ارتفاع از سطح دريا متغير است.

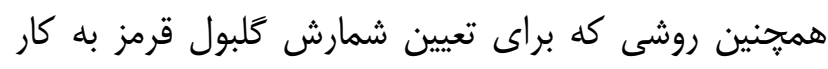

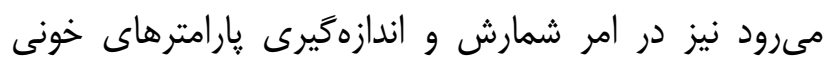
مهرم خواهد بود (IV). شهرستان بيرجَند در استان خراسان

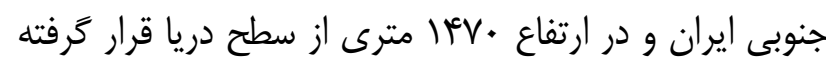

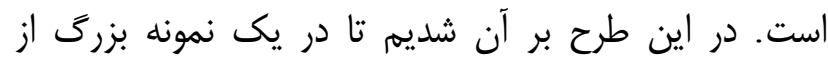

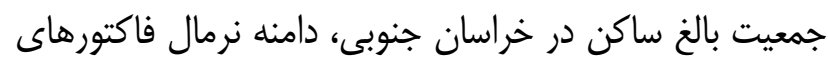

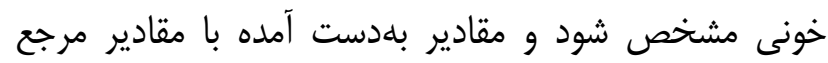

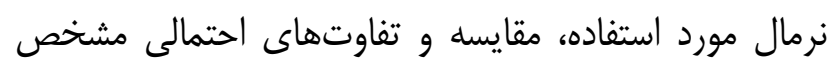

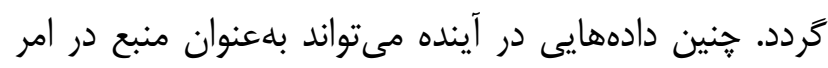
تحقيق و تشخيص، مورد استفاده و استناد قرار گيرند.

\section{روش تحقيق}

در اين طرح جامع جامعلمحور كه با هدف تعيين شيوع هياتيت ويروسى در شهر بيرجند در سال عاوسا انجام شده،

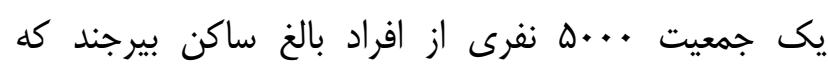

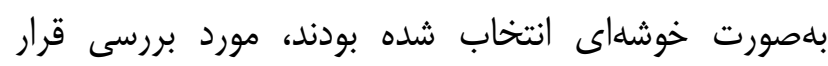

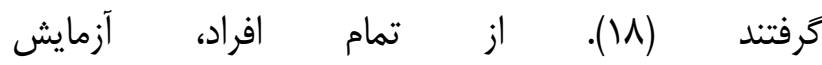
توسط يك دستخاه (CBC) Complete Blood Count سل كانتر كاليبره (مدل سيسمكس XS 800i) انجام گرفت. لازم به توضيح است كه دادههاى مطالعه حاضر مربوط بله

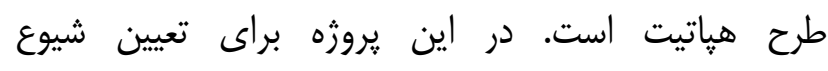
بيمارىهاى عفونى در سطح شهر بيرجند، ل...0 نفر از افراد بالاى ها سال به روش خوشهاى تصادفى انتخاب شدند.

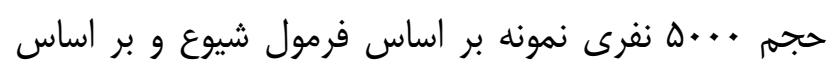

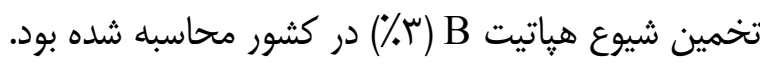

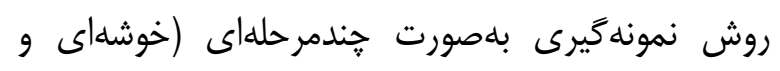

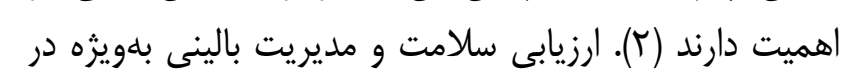

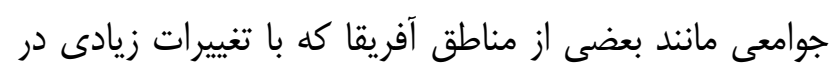

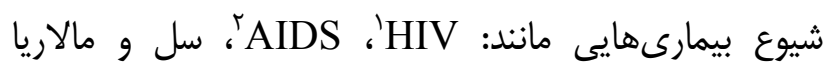

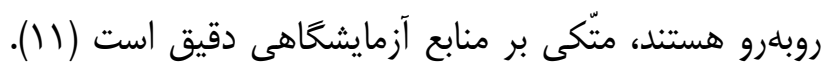
در واقع همان طور كه در بحث كنترل كيفى آزمايشگاه نيز

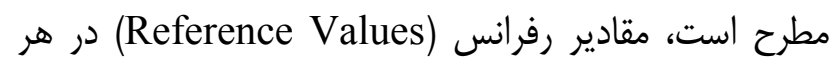

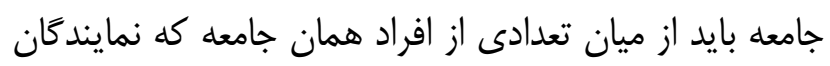

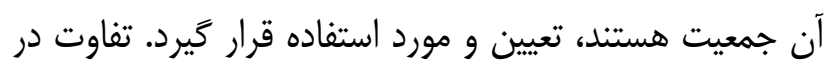
مقادير رفرانس خونشناسى در بين جمعيتهاى آسيايى و ورئن

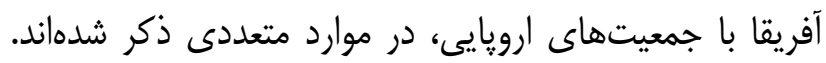

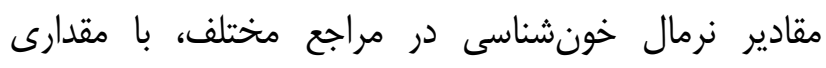

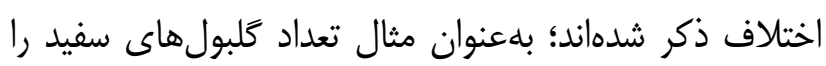

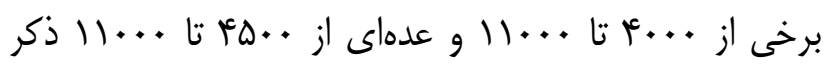
كردهاند. به هر حال بسيارى از مؤلفين در بيان مقادير نرمال

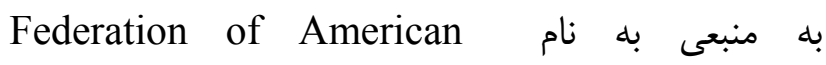
Experimental Societies for Biology

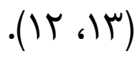

اين نكته مسلم است كه آمار دقيقى از محدوده يارامترهاى نرمال خونشناسى در كشور ما در دست نيست و

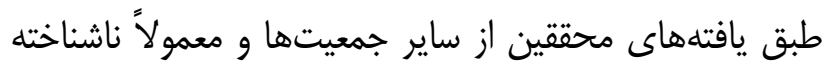
ذكر مى

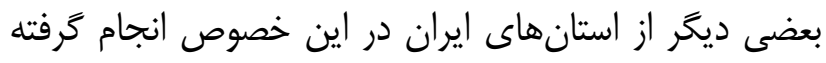

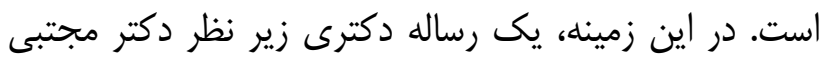

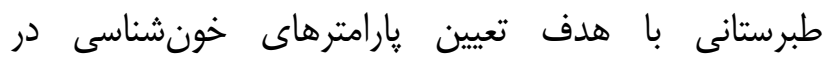

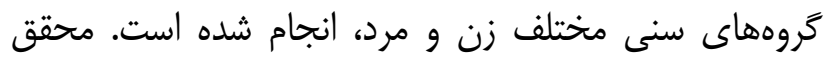

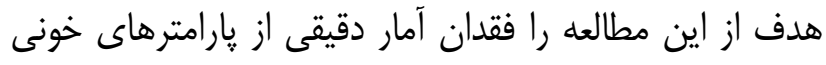

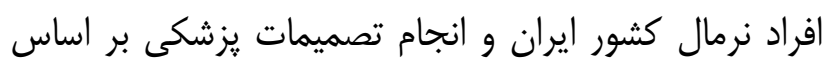
يافتههاى مؤلّفين ديخر تصميه، عنوان نموده است. هر خهند

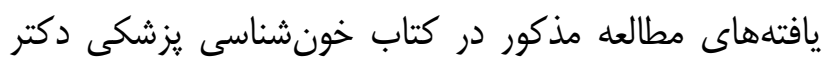


بود. اين مطالعه در كميته اخلاق دانشكاه علوم يزشكى بيرجند با كد

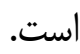

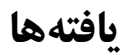

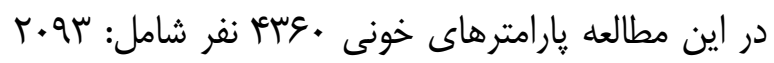

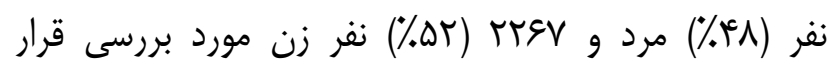

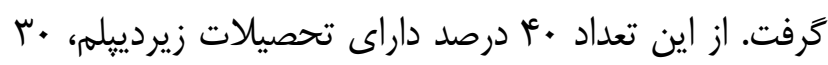

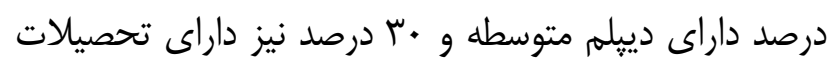

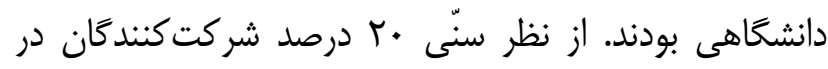

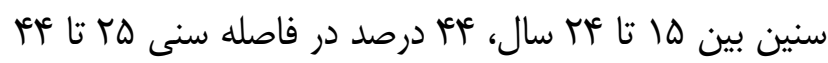

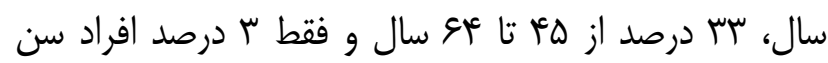
بالاتر از ه ه سال داشتند.

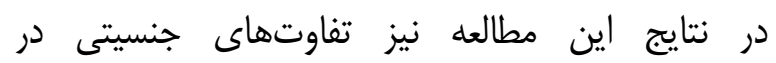

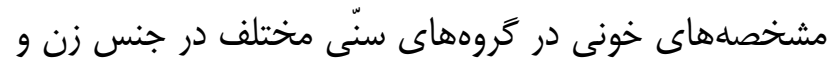

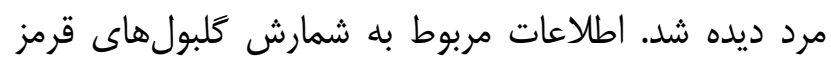
(RBC) شاخصهاى كَلبولهاى قرمز شامل: MCV

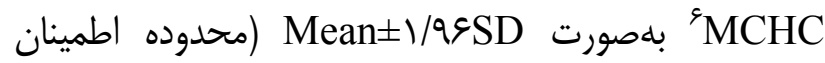
ه \%٪) به تفكيك سن و جنس در جدول يك نمايش داده شده

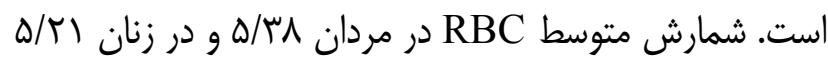

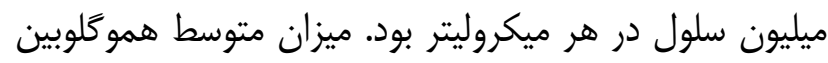

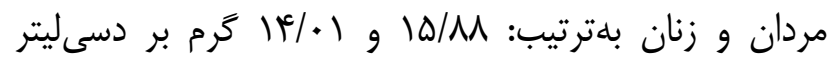
خون بهدست آمد. متوسط حجم كلبولى (MCV) مردان

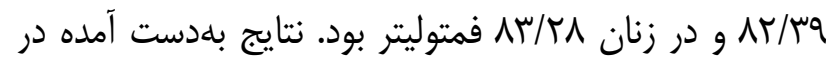

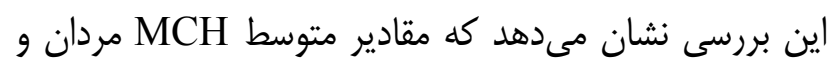

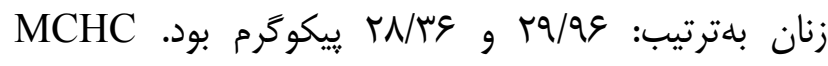
بلمعناى مقادير هموكلوبين در مقايسه با حجم كلئين

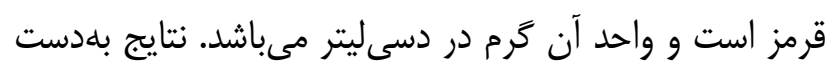

\footnotetext{
${ }^{1}$ Red Blood cell count

${ }^{2}$ Hemoglobin

${ }^{3}$ Hematocrit

${ }^{4}$ Mean corpuscular volume

${ }_{6}^{5}$ Mean corpuscular Haemoglobin

${ }^{6}$ Mean corpuscular Haemoglobin concentration
}

تصادفى) بود؛ به اين صورت كه از اداره يست شهرستان

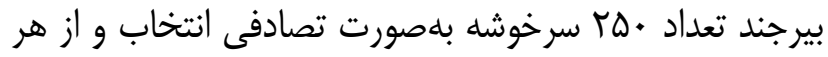

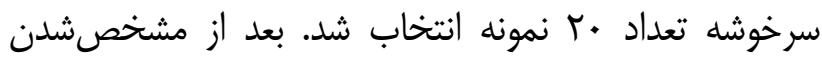

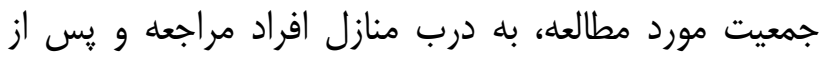

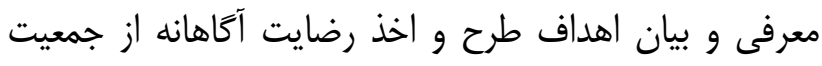

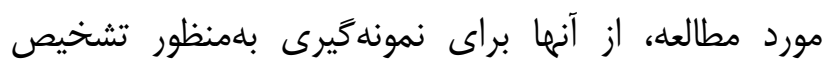

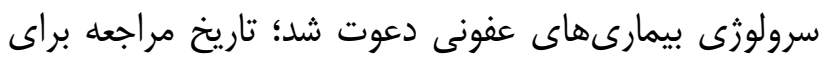

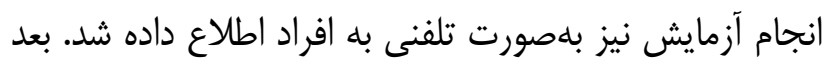

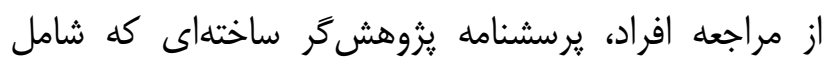

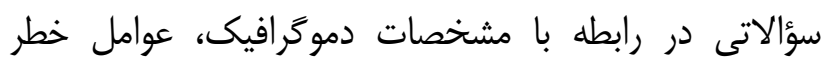

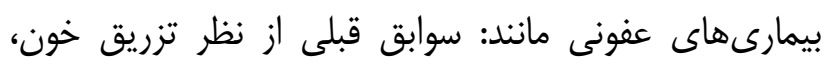

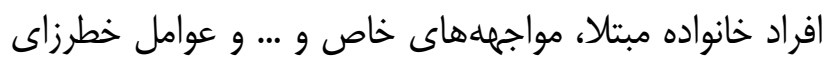
بيمارىهاى قلبى مانند: مصرف دخانيات، سابقه فاميلى مانى بيمارى قلبى و ... بود، با روش مصاحبه براى بيماران تكميل

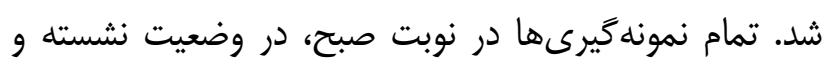

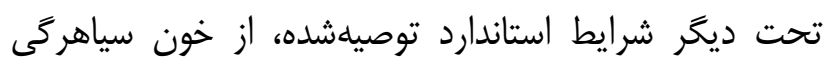

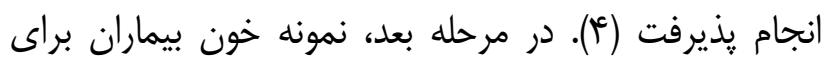

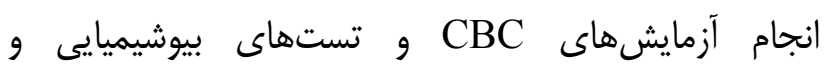

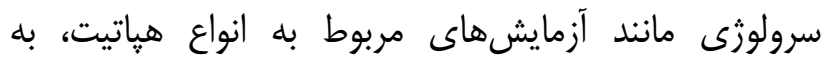

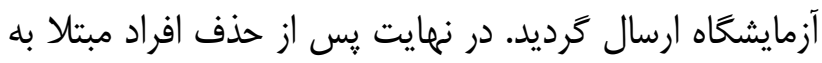
بيمارهاى مزمن عفونى و غيرعفونى، بيمارىهاى صعب العلاج

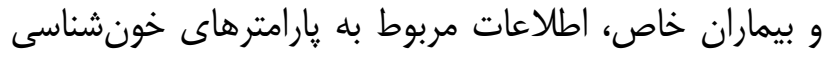

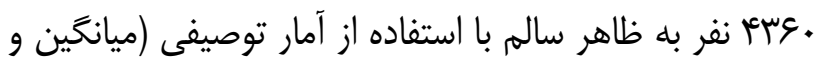
انحراف معيار) براى هر كدام از يارامترهاى مورد مطالعه، محاسبه و مورد تجزيه و تحليل قرار گرفت.

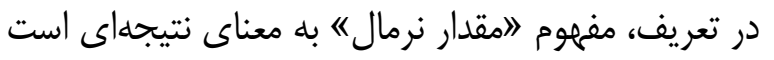

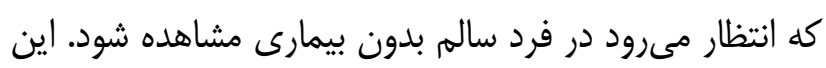

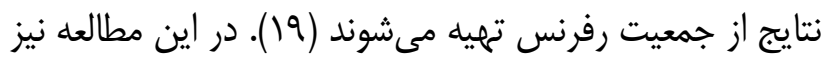

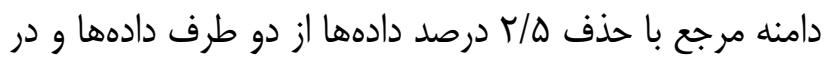

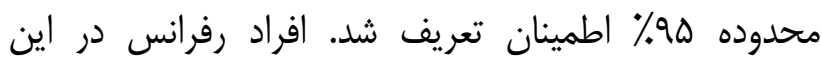

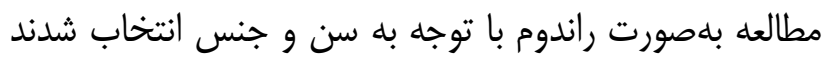

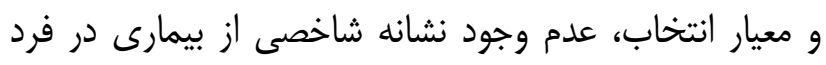




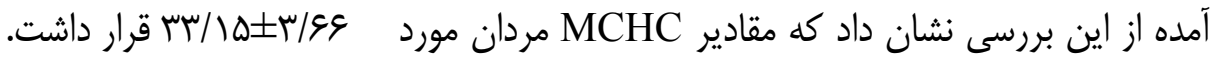

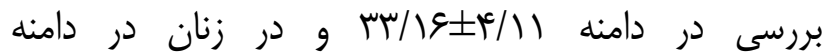

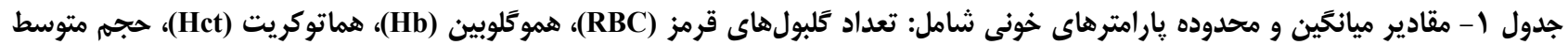

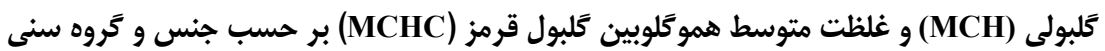

\begin{tabular}{|c|c|c|c|c|c|c|c|c|}
\hline \multicolumn{8}{|c|}{ جنس و سن } & \multirow{3}{*}{ شاخص } \\
\hline \multirow{2}{*}{$\begin{array}{c}\text { ميانكين كل در } \\
\text { زنان } \\
(\bar{x} \pm \text { SD) }\end{array}$} & \multicolumn{3}{|c|}{ زن } & \multirow{2}{*}{$\begin{array}{c}\text { ميانَين كل در } \\
\text { مردان } \\
(\bar{X} \pm \text { SD) }\end{array}$} & \multicolumn{3}{|c|}{ مرد } & \\
\hline & 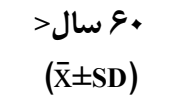 & 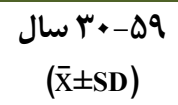 & 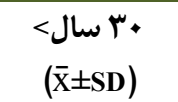 & & 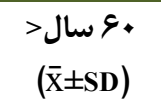 & $\begin{array}{c}{ }^{\top}+\Delta q \\
(\bar{x} \pm S D)\end{array}$ & $\begin{array}{c}\text { •r سال } \\
(\bar{X} \pm \text { SD) }\end{array}$ & \\
\hline$\Delta / r \mid \pm 1 / q F$ & $\Delta / \cdot V \pm I / r q$ & $\kappa / १ \vee \pm 1 / \Upsilon \wedge$ & $r / q \xi \pm 1 / r q$ & $\Delta / \Lambda \pm \Gamma / \cdot \Delta$ & $\Delta / \mu^{\prime} \wedge \pm 1 /{ }^{\prime} \Delta$ & 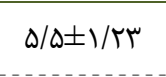 & $\Delta / V \pm 1 /{ }^{\alpha}$ & $\begin{array}{c}\mathrm{RBC} \\
\left(10^{6} / \mu \mathrm{l}\right)\end{array}$ \\
\hline $\mid f / \cdot 1 \pm 1 / \Lambda$ & $\mid r / I V \pm r / \|$ & $|r / \Lambda \Gamma \pm r / F|$ & $\mid r / q \pm r / \|$ & سו/ & $|\omega / \Delta| \pm r /||$ & $1 Q / V \& \pm r / \& Y$ & $\mid \omega / \mathcal{M} \pm \Psi / \cdot 1$ & $\begin{array}{c}\mathrm{HB} \\
(\mathrm{gr} / \mathrm{dl})\end{array}$ \\
\hline$F T / \Delta Q \pm \Delta / ৭ q$ & $r T / V Q \pm \varepsilon / \cdot r$ & $|f| / N \pm s / r \mid$ & $|\varphi| / V \mid \pm 0 / \& \varepsilon$ & $\Gamma \Delta / \Lambda) \pm V / \Delta r$ & rब/৭৭ $\pm V / \wedge r$ & $\uparrow \varepsilon / \% q \pm ه / \wedge q$ & $\mid \varepsilon / \wedge \mathrm{r} \pm \varepsilon / \cdot V$ & $\begin{array}{c}\mathrm{HCT} \\
(\%)\end{array}$ \\
\hline$\Lambda \Upsilon / \Upsilon \Lambda \pm I V / \Delta \digamma$ & ع & $\Lambda \kappa / g r \pm I r / V V$ & $\Lambda F / g r \pm I r / r \varepsilon$ & $1 r / r q \pm 1 q / q$ & $\Lambda \varepsilon / \cdot q \pm 1 \mu / \kappa$ & $\wedge \kappa / ৭ \pm|r / r|$ & $\Lambda \mu \pm 1 \Delta / \kappa^{c}$ & $\begin{array}{l}\mathrm{MCV} \\
(\mathrm{fL})\end{array}$ \\
\hline 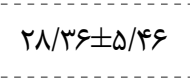 & $r N|q| \pm r / \cdot q$ & $r N / \Delta \pm r / V T$ & $r N / G T \pm Y / \Delta F$ & $r N / Q \Delta \pm T / / V$ & $r q / r \Delta \pm r / \uparrow q$ & $r q / \mu) \pm r / \Delta$ & $r N / q T \pm T^{c} / V^{c}$ & $\begin{array}{c}\mathrm{MCH} \\
\mathrm{pg}\end{array}$ \\
\hline ع & $m / / \neg 1 \pm r / \cdot 1$ & 更/ & & $m / 1 \varepsilon \pm \psi / \| 1$ & $r / \Lambda F \pm r / r)$ & $r F / . q \pm r / r \Delta$ & $r F / \cdot q \pm r / v \wedge$ & $\begin{array}{c}\mathrm{MCHC} \\
(\mathrm{g} / \mathrm{dl})\end{array}$ \\
\hline
\end{tabular}

RBC: Red Blood cell, Hb: Hemoglobin, Hct: Hematocrit, MCV: Mean corpuscular volume, MCH: Mean corpuscular Haemoglobin, MCHC: Mean corpuscular hemoglobin concentration

جدول r- ميانكَين و انحراف معيار متغير هاى گَلبول هاى سفيد، نوتروفيل، لنفوسيت، منوسيت، ائوزينوفيل و پالاكت بر حسب جنس و گروه سنى

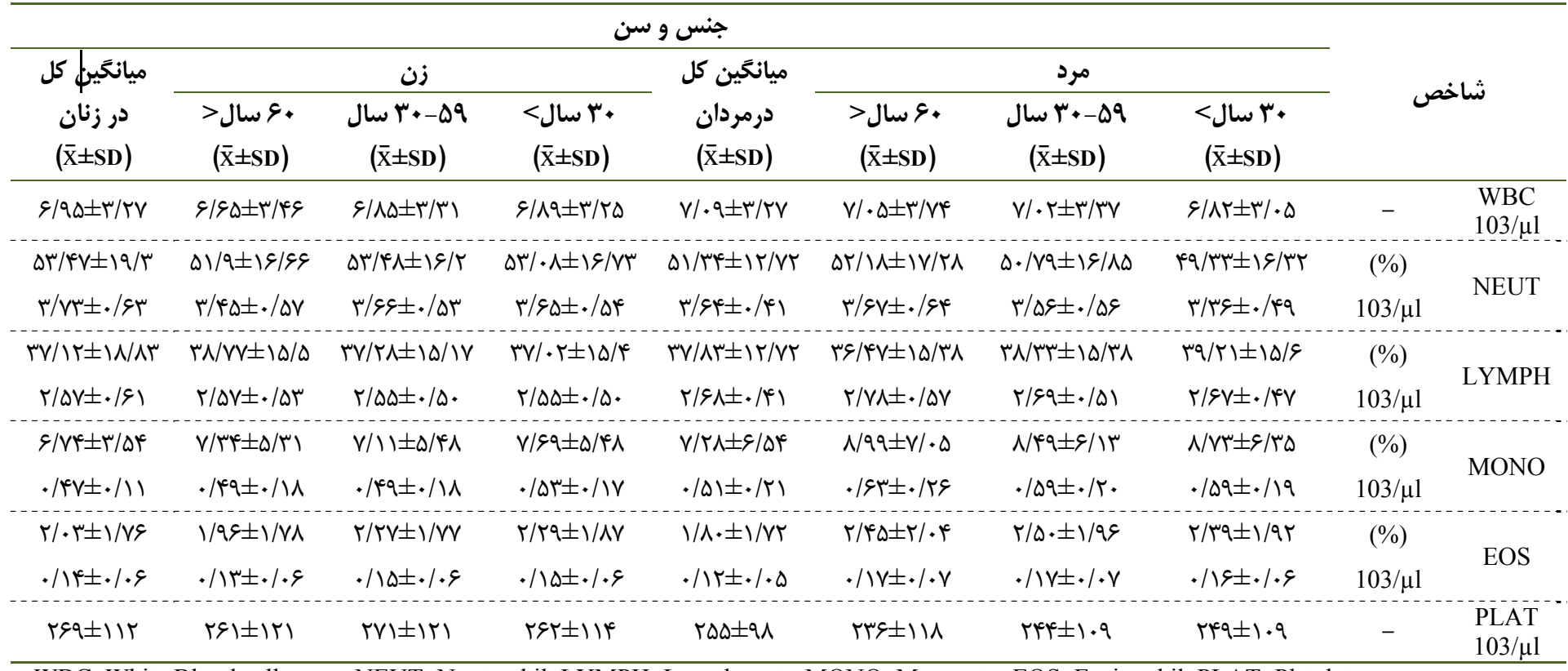

WBC: White Blood cell count, NEUT: Neutrophil, LYMPH: Lymphocyte, MONO: Monocyte, EOS: Eosinophil, PLAT: Platelet 
اين دادهها تحت تأثير يك طيف وسيع از فاكتورهاى زنتيك،

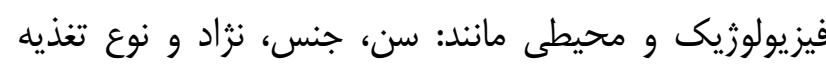

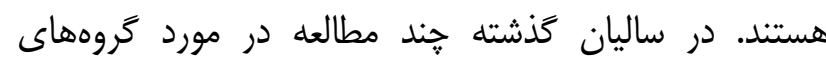
جمعيتى محدودى در خصوص تعيين مقادير و و دامنه هارامترهاى خونى در ايران صورت كرفتنه، ولى عمده آنها بردي

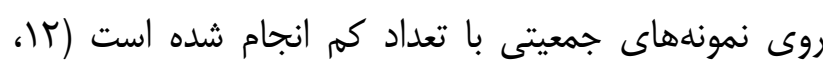

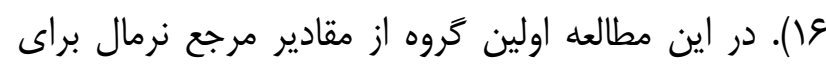
افراد سالم، از يك جمعيت بزرى بلهظاهر سالم در خراسان

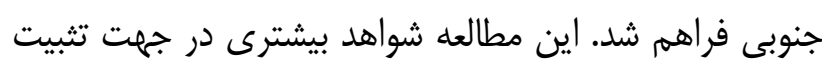

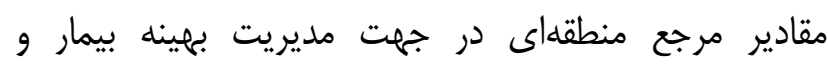
تحقيقات يزشكى فراهم كرد.

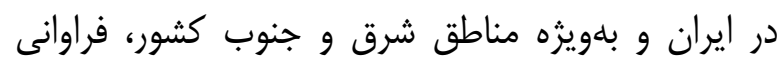

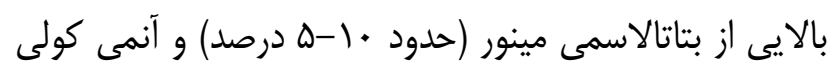

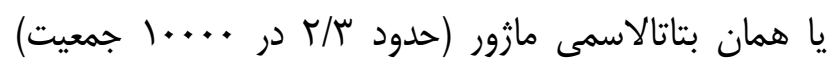

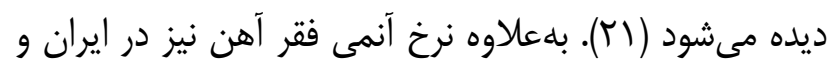

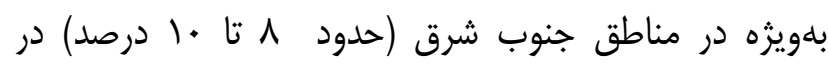

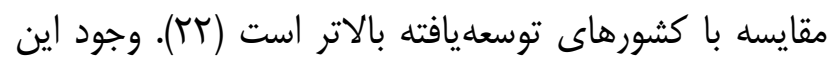

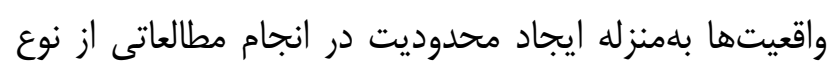
مطالعه حاضر است؛ زيرا تشخيص دقيق و خروج همه موارد

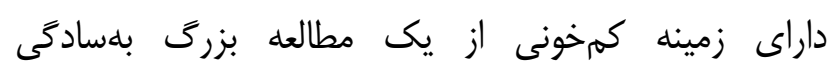
امكانيذير نيست. در ساير مطالعات صورتخرفته بر روى رونى

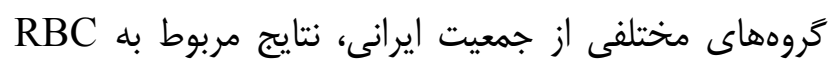

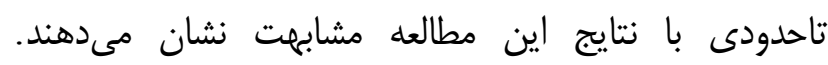

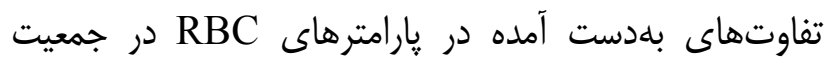

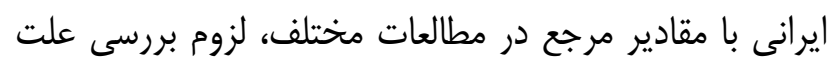

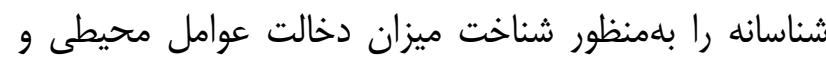

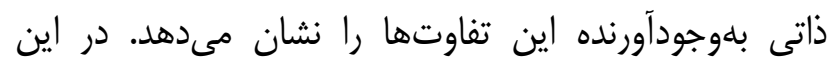

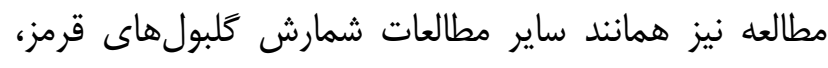

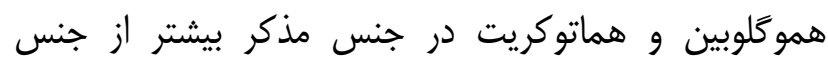

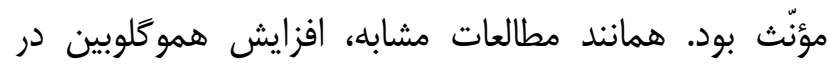

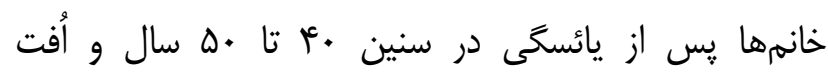

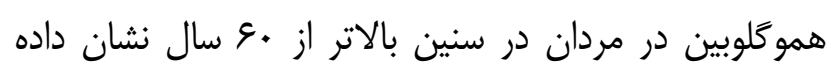

اطلاعات مربوط به شمارش كلبولهاى سفيد' شامل:

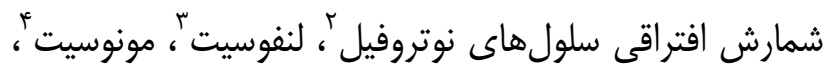

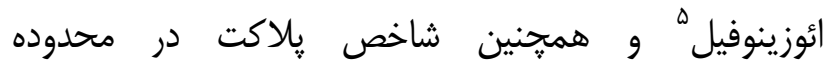
Al/9\&SD به تفكيك سن و جنس نمايش داده شده است.

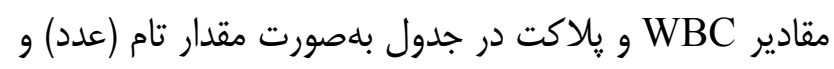

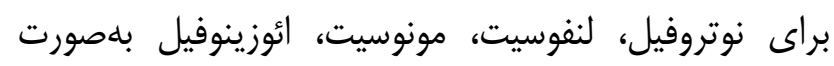

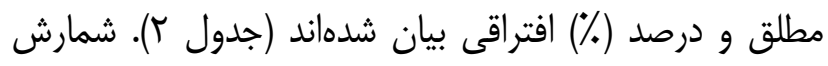
تام لكوسيتى در مردان كمى بيشتر از زنان بود. اين مقادير

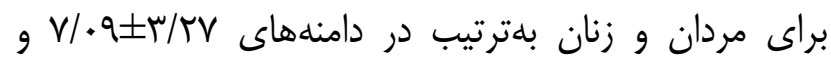

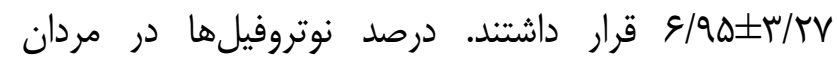
نف لنفوسيتها در مردان

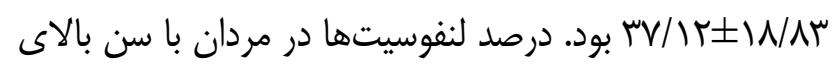

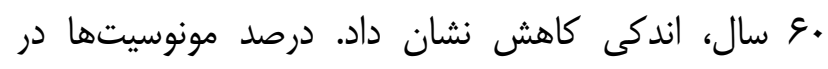
مردان دامنه تغييرات مونوسيتى در مردان به شكل قابل ملاحظهاى

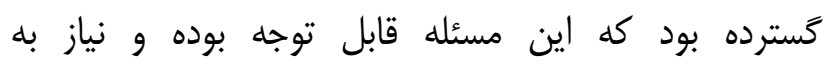

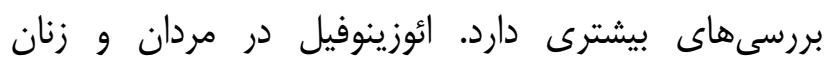

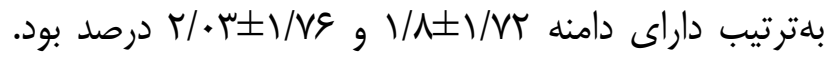
تعداد קلاكت در مردان

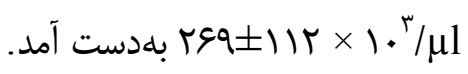

يارامترهاى خونشناسى و دانش مربوط به آن مىتواند در

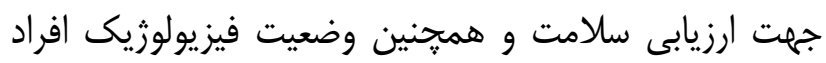

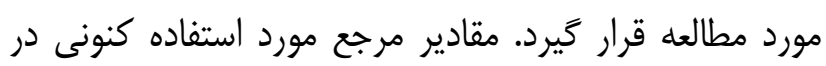

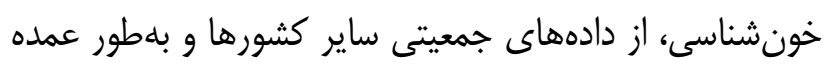

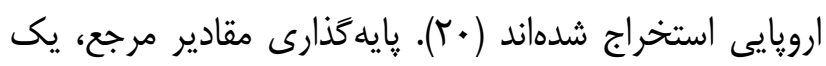
اساس مهم براى تفسير كلينيكى دادهاى آزمايشگاهى است.

\footnotetext{
${ }^{1}$ White Blood cell count(WBC)

${ }^{2}$ Neutrophil(Neut)

${ }^{3}$ Lymphocyte(lym)

${ }^{4}$ Monocyte (mono)

${ }^{5}$ Eosinophil(Eos)
} 
جدول ب- مقايسه مقادير MCH و MCV ،Het ،Hb RBC،WBC ، MCHC در مطالعه حاضر با نتايج مطالعات مشابه

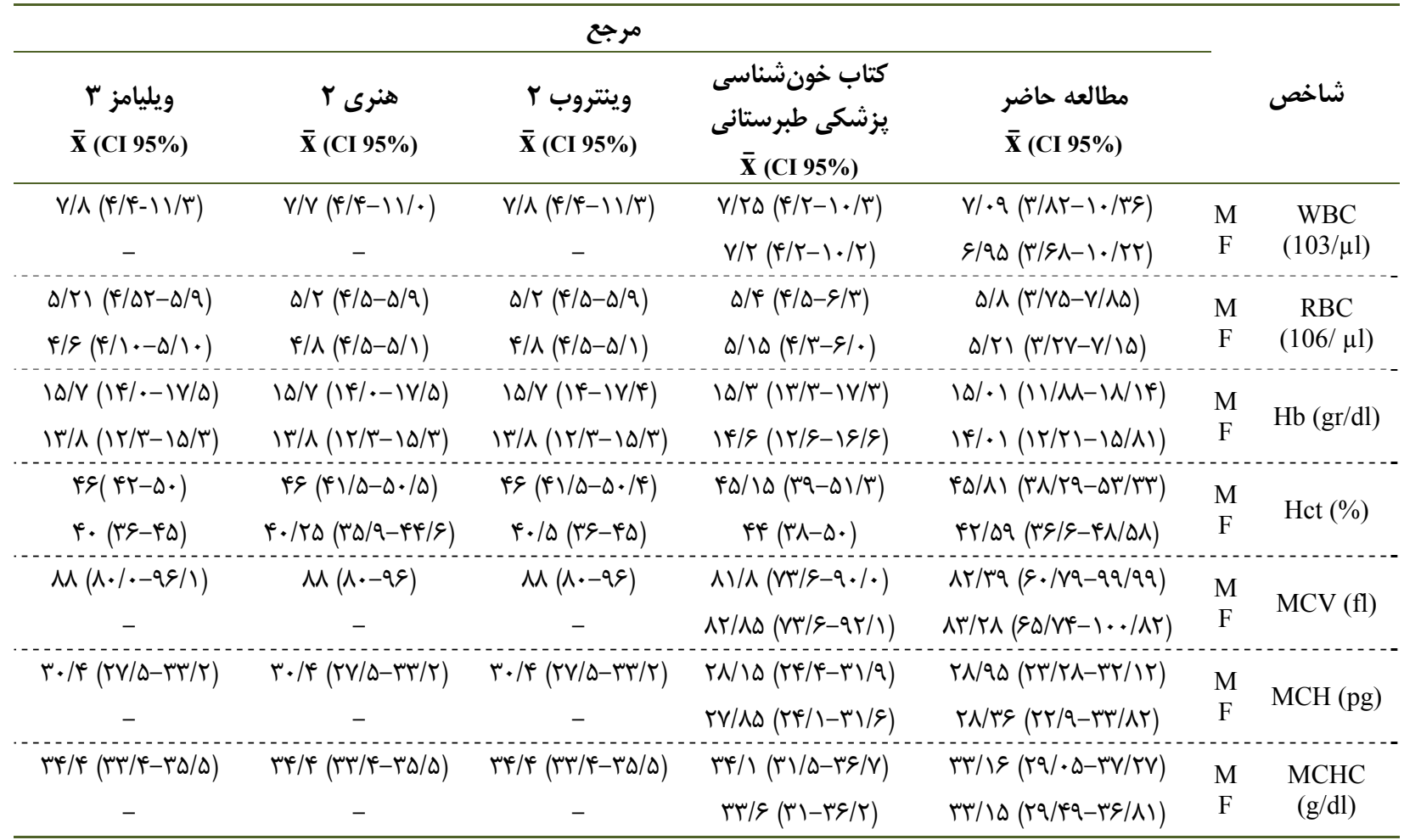

داراى مقادير متوسط بالاترى از كلبولهاى سفيد هستند.

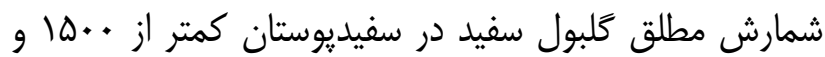

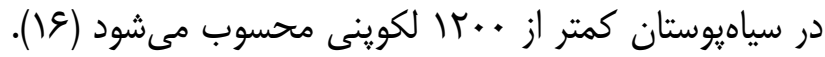
بر همين اساس مقادير WBC در جمعيت ساكن در منطقه

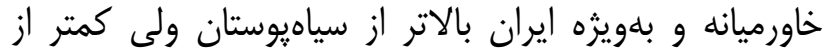

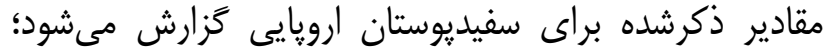

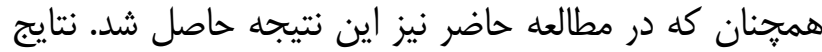

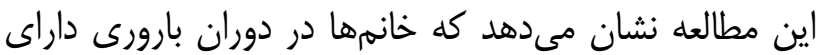
شمارش بالاتر لكوسيتى و بهويزه نوتروفيل نسبت به مردان

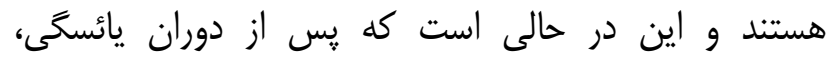

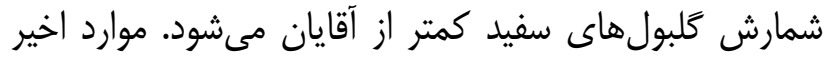

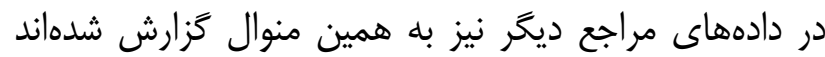
در اين مطالعه دامنه تغييرات منوسيتى در مردان (T/N/Tال

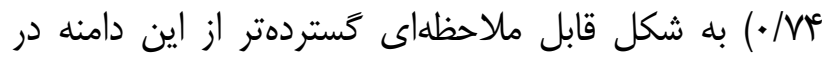

در جدول ب نتايج مربوط به شمارش كلّى لكوسيتها

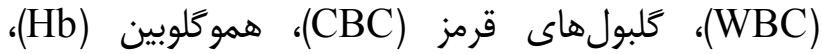
هماتوكريت (Hct)، حجم متوسط كلبولى (MCV)، ميزان (MCV)،

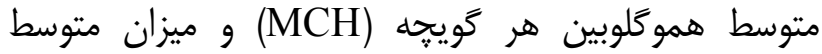
غلظت هموكلوبين كلبولى (MCHC) در اين مطالعه بههمراه

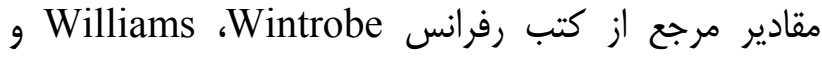
Henry در جنس مذكر و مؤنّن آورده شده است (بآ، •r.

بلهطور كلى نتايج اين مطالعه نشان مىدهد، مقدار متوسط WBC اندكى كمتر از مقادير مرجع و در خصوص

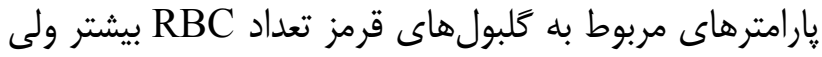

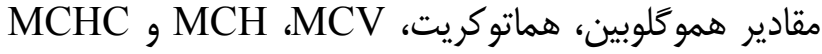
كمتر از مقادير ذكرشده در استانداردهاى جهانى استى

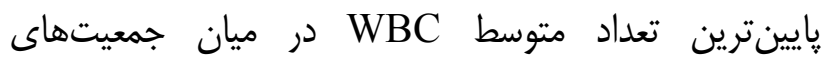
سياهيوست آفريقايى كزارش مىشود و سفيديوستان قفقازى 
از محدوديتهاى اين مطالعه، عدم امكان انجام

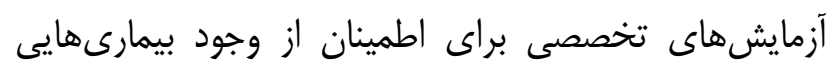

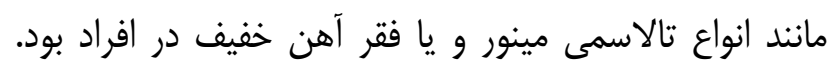

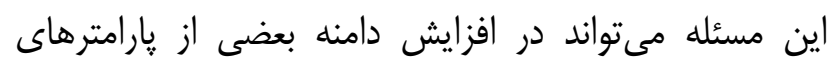
RBC

\section{نتيجه تيرى}

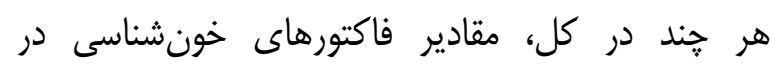

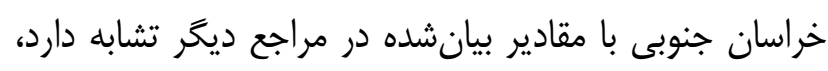

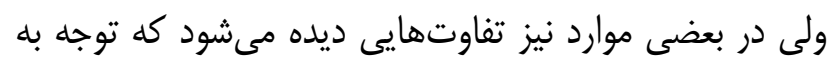

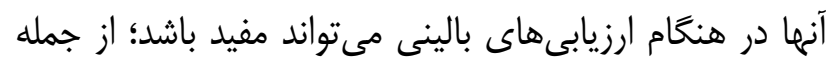

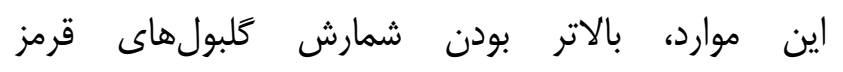
و ميزان همو گلوبين بلويزه در مردان است.

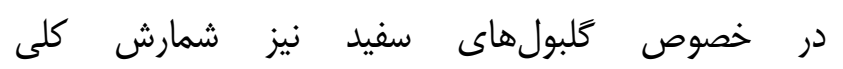
يايينتر از ميزان بيانشده در مراجع موجود (Total WBCs) است؛ ولى درصد ائوزينوفيل و مونوسيت بالاترى در بين افين افراد اين مطالعه بلهدست آمد.

\section{تقل ير و تشكر}

از همكارى معاونت محترم تحقيقات و فناورى و يرسنل

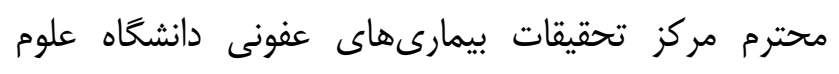
يزشكى بيرجند در اجراى اين يزوهش تقدير مى تردد.

\section{تضاد منافع :}

نويسندكان مقاله اعلام مى دارند كه هيجَّونه تضاد منافعى در يزوهش حاضر وجود ندارد.

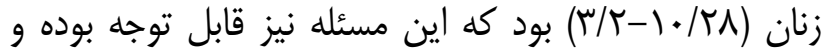
مىتواند مورد مطالعه بيشترى قرار كيرد. نتايج همجنين نشان

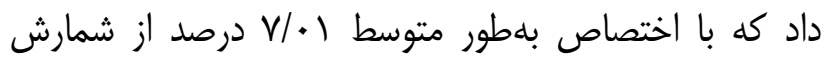
افتراقى به منوسيتها، دامنه تغييرات مونوسيتها در جمعيت إنهاص

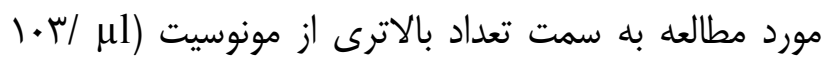

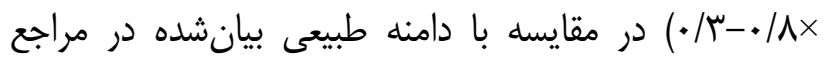

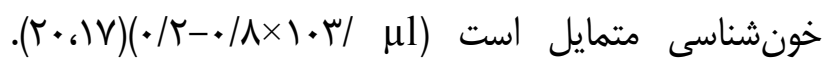

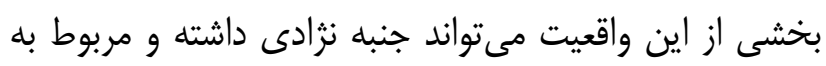

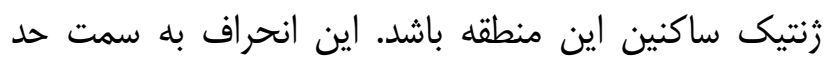

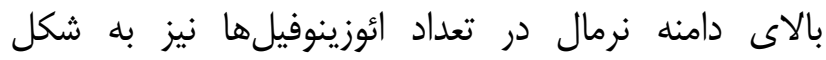

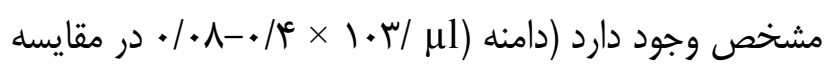

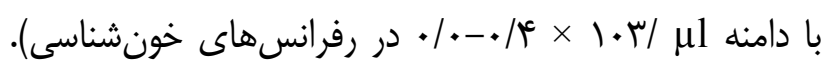

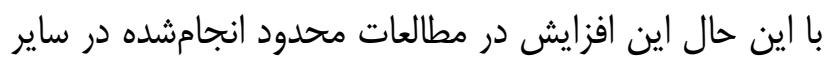

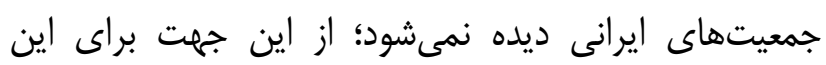

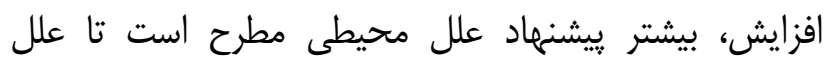

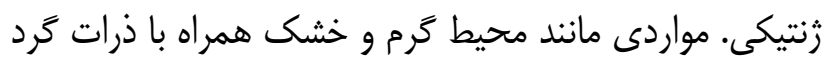

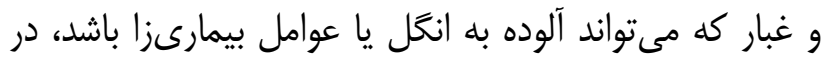

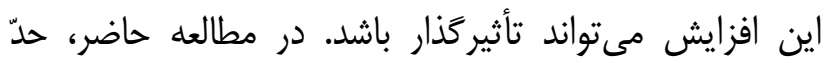

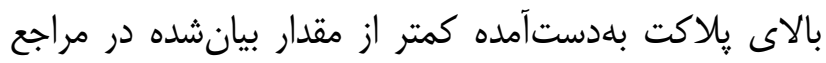

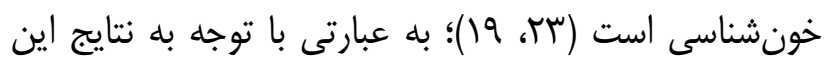

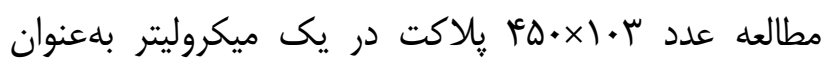

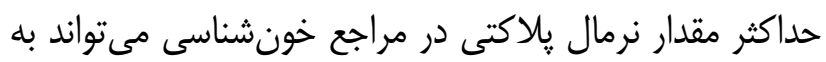

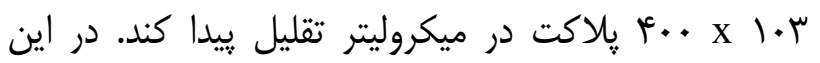

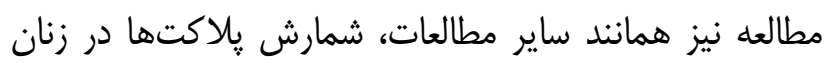

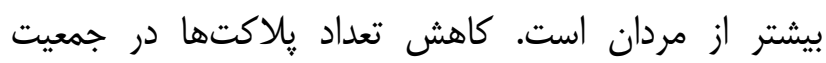
آفريقايى نسبت به سفيديوستان ارويايى نيز در مطالعات ديخر

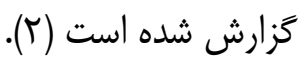

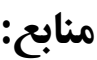

1- Dacie SJV, Lewis SM. Reference Ranges and Normal values. In: Practical Hematology. 8th ed. UK: Churchill Livingstone; 1994. p. 9-19.

2- Roberts WL, McMillin GA, Burtis CA, Bruns DE. Reference information for the clinical laboratory. In: Burtis CA, Ashwood ER, Bruns DE, editors. Tietz Textbook of Clinical Chemistry and Molecular Diagnostics. 4th ed Elsevier Saunders; St. Louis: 2006. pp. 2251-318. 
3- Kone B, Maiga M, Baya B, Sarro YDS, Coulibaly N, Kone A, et al. Establishing Reference Ranges of Hematological Parameters from Malian Healthy Adults. J Blood Lymph. 2017; 7(1). pii: 154. doi: 10.4172/2165-7831.

4- El-Hazmi MA, Warsy AS. Normal Reference Values For Hematological Parameters, Red Cell Indices, Hb A2 and Hb F From Early Childhood Through Adolescence in Saudi. Ann Saudi Med. 2001; 21(3-4): 165-9. DOI: 10.5144/02564947.2001.165

5- Dacie JV, Lewis SM. Practical Haematology. $7^{\text {th }}$ ed. London: Churchill Livingstone; 1991.

6- Kelly A, Munan L. Haematological profile of natural populations: red cell parameters. Br J Haematol. 1977; 35(1): 153-60.

7- Taylor MR, Holland CV, Spencer R, Jackson JF, O’Connor GI, O’Donnell JR. Haematological reference range for school children. Clin Lab Haematol. 1997; 19(1): 1-15.

8- El-Hazmi MA, Al-Faleh FZ, Al-Mofleh IA, Warsy AS, Al-Askah AK. Establishment of normal "reference" ranges for haematological parameters for healthy Saudi Arabs. Trop Geogr Med. 1982; 34(4): 333-9.

9- Odutola AA, Afolabi MO, Jafali J, Baldeh I, Owolabi OA, Owiafe P, et al. Haematological and biochemical reference values of Gambian infants. Trop Med Int Health. 2014; 19(3): 275-83. doi: 10.1111/tmi.12245.

10- Adetifa IM, Hill PC, Jeffries DJ, Jackson-Sillah D, Ibanga HB, Bah G, et al. Haematological values from a Gambian cohort-possible reference range for a West African population. Int J Lab Hematol. 2009; 31(6): 615-22. doi: 10.1111/j.1751-553X.2008.01087.x.

11- Tembe N, Joaquim O, Alfai E, Sitoe N, Viegas E, Macovela E, et al. Reference values for clinical laboratory parameters in young adults in maputo, Mozambique. PLoS one. 2014; 9(5): e97391. doi:10.1371/journal.pone.0097391.

12- Rasouli M, Pourmokhtar M, Sarkardeh S. Hematological Reference Intervals for Healthy Iranian Blood Donors. Int J Hematol Oncol Stem Cell Res. 2017; 11(4): 305-12.

13- Rashid M, Majid OB, Dehghani M, Karimi M. Normal Hemoglobin and Hematological Indices in Southwest of Iran. IJBC. 2009; 1(3): 99-102.

14- Keramati MR, Mohammadzadeh A, Farhat AS, Sadeghi R. Determination of Hematologic Reference Values of Neonates in Mashhad - Iran. International Journal of Hematology and Oncology. 2011; 21(2): 101-105.

15- Tabarestani M, Keramati MR, Maroozi F, Keramati A. The determination of hematologic reference values oriented by sex and age in general population of Mashhad. Horizon Med Sci. 2007; 13(2): 27-33. [Persian]

16- Tabarestani M. Medical Hematology. Mashhad: Mashhad University Press; 1985. [Persian]

17- Wintrobe MM, Greer JP. Wintrobe's clinical hematology. Philadelphia: Wolters Kluwer Health/Lippincott Williams \& Wilkins; 2009.

18- Ziaee M, Ebrahimzadeh A, Azarkar Z, Namaei MH, Saburi A, Fereidouni M, et al. Seroprevalence and Risk Factors for Hepatitis B in an Adult Population: The First Report from Birjand, South Khorasan, Iran. Hepat Mon. 2016; 16(9): e36452. doi:10.5812/hepatmon.36452

19- Kaushansky K, Williams WJ. Williams hematology. New York: McGraw-Hill Medical; 2010.

20- Keramati MR, Mohammadzadeh A, Shah Farhat A. The determination of hematologic sreference values in neonates in Mashhad. Horizon Med Sci. 2010; 16(1): 64-71. [Persian]

21- Moradi Gh, Ghaderi E. Chronic disease program in Iran: Thalassemia control program. Chron Dis J. 2013; 1(2): 98106.

22- Alipoor R, Gholami MS, Heidari-Soureshjani R, Rajabi MR, Anari MJ, Vaziri MS, et al. The Prevalence of Iron Deficiency Anemia among High School Students in Iran: A Systematic Review. Internal Medicine and Medical Investigation Journal. 2017; 2(1): 1-6. doi: 10.24200/imminv.v2i1.45

23- Henry JB, McPherson RA, Pincus MR. Henry's clinical diagnosis and management by laboratory methods. $22^{\text {nd }}$ ed. Philadelphia, PA: Elsevier/Saunders; 2011. 